\title{
PENERAPAN MIND MAPPING SEBAGAI MEDIA DALAM MENINGKATKAN KEMAMPUAN BELAJAR IPS PADA SISWA KELAS VII MTS MANBAUL BAYAN SAKRA
}

\author{
FIZIAN YAHYA \\ STAI Darul Kamal NW Kembang Kerang Lotim NTB \\ fizian1989@gmail.com \\ BAIQ YAYUK SAMSINIWATI \\ STAI Darul Kamal NW Kembang Kerang Lotim NTB \\ yayukbaik16@gmail.com
}

\begin{abstract}
ABSTRAK
Latar belakang masalah berorientasi pada penggunaan media pembelajaran yang menggunakan media berbasis komputer. Padahal tidak semua daerah di Indonesia sudah mempunyai sarana dan prasarana yang memadai untuk melaksanakan pembelajaran berbasis media komputer sehingga pembelajaran terbatasi oleh adanya sarana dan prasarana tersebut. Rumusan masalah penelitian ini adalah apakah penerapan Mind Mapping sebagai media dapat meningkatkan kemampuan belajar IPS pada siswa kelas VII Manbaul Bayan Sakra. Tujuan penelitian ini adalah 1) untuk meningkatkan kreativitas guru dalam mengembangkan media, 2) untuk meningkatkan aktivitas belajar siswa, 3) untuk meningkatkan kemampuan belajar siswa. Penelitian dilakukan melalui tiga siklus, dimana masing-masing siklus melakukan tindakan perencanaan, pelaksanaan, pengamatan, dan refleksi. Subyek penelitian ini adalah siswa kelas VII Mts Manbaul Bayan Sakra yang berjumlah 15 siswa. Data hasil belajar siswa diperoleh melalui tes penilaian posttest, dengan lembar observasi aktivitas siswa sebagai pendukung. Analisis data hasil belajar siswa setelah tindakan siklus I dapat diketahui bahwa nilai rata-rata 53,57 dengan ketuntasan belajar klasikal mencapai 25\%. Setelah tindakan siklus II nilai rata-rata 72,31 dengan ketuntasan belajar klasikal 76,92\%, Hasil analisis aktivitas siswa pada tindakan siklus I diperoleh hasil $60 \%$ dengan kriteria cukup. Aktivitas siswa pada siklus II mencapai 73,33\% dengan kriteria baik. Dari analisis data penelitian dengan judul Penerapan Mind Mapping sebagai Media dalam Meningkatkan Kemampuan Belajar IPS pada Siswa Kelas VII Mts Manbaul Bayan Sakra dapat meningkatkan kemampuan belajar serta aktivitas siswa dalam pembelajaran. Berdasarkan hasil penelitian ini disarankan agar guru memanfaatkan media Mind Mapping dalam pembelajaran agar dapat meningkatkan pemahaman siswa serta meningkatkan kemampuan belajar siswa.
\end{abstract}

Kata Kunci: mind mapping, media, kemampuan belajar 


\section{PENDAHULUAN}

Pendidikan Ilmu Pengetahuan Sosial (IPS) merupakan salah satu pondasi dari kemampuan sains dan teknologi. Dan ips juga memiliki peran penting dalam pendidikan. Mengingat pentingnya ips dalam pengembangan generasi, maka siswa tidak boleh dibiarkan jenuh dalam belajar ips yang dikarenakan menganggap ips sebagai pelajaran yang menjenuhkan. pendidikan yang baik adalah pendidikan yang tidak hanya mempersiapkan para siswanya untuk suatu profesi atau jabatan, tetapi untuk menyelesaikan masalah-masalah yang dihadapinya dalam kehidupan sehari-hari. Untuk mewujudkan tujuan pendidikan tersebut, di sekolah perlu dilaksanakan pembelajaran yang komprehensif, mulai dari pendidikan agama, pendidikan moral, pendidikan estetika, serta ilmu pengetahuan dan teknologi. Salah satu masalah pokok dalam pembelajaran pada pendidikan formal (sekolah) adalah rendahnya daya serap peserta didik dalam pembelajaran. Hal ini merupakan akibat dari kondisi pembelajaran yang masih bersifat konvensional dan tidak menyentuh ranah dimensi peserta didik itu sendiri yaitu mengenai bagaimana sebenarnya belajar itu. Dalam arti substansial, proses pembelajaran hingga saat ini masih terdominasi guru dan kurang memberikan akses bagi peserta didik untuk berkembang secara mandiri melalui penemuan dan proses berpikirnya. ${ }^{1}$

Untuk mengatasi masalah tersebut di atas, diperlukan suatu media pembelajaran yang dapat meningkatkan aktivitas siswa dan meningkatkan hasil belajar siswa. Dalam penggunaan media belajar, seringkali apabila mendengar kata media belajar, pikiran kita langsung tertuju kepada media pembelajaran canggih seperti Powerpoint, Flash, Mobile Learning, dan lain sebagainya yang menggunakan teknologi modern. Namun ternyata hal tersebut masih didominasi oleh satuan pendidikan yang berada di daerah maju dengan infrastruktur yang mendukung jalannya aktivitas pembelajaran dengan media canggih. Keterbatasan media dan fasilitas pendukung pelaksanaan media tersebut masih belum dapat dipenuhi oleh sebagian besar satuan pendidikan di daerah yang terletak di daerah pedesaan. Daerah yang terletak di pedesaan, cenderung belum terjamah oleh teknologi semacam itu sehingga masih diperlukan media yang dapat diaplikasikan dalam pembelajaran konvensional yang dilaksanakan di daerah tersebut dengan perlengkapan yang terbilang seadanya sesuai dengan kemampuan satuan pendidikan dan peserta didik. Pembelajaran yang dilaksanakan sebagian besar masih menganut pembelajaran konvensional karena keterbatasan sarana teknologi yang dimiliki. Sekolah ini hanya memiliki satu buah perlengkapan LCD Proyektor, sehingga penggunaannya harus bergantian dengan kelas yang lain. Selain itu belum tersedianya media pembelajaran yang berbasis computer.

Salah satu cara untuk mengatasi permasalahan tersebut adalah dengan menggunakan media belajar yang mudah dibuat dan digunakan oleh guru yang belum dapat mengoperasionalkan komputer. Media tersebut adalah media yang digunakan untuk memetakan pikiran yang lebih

${ }^{1}$ (Trianto, 2007:1). 
dikenal dengan Mind Mapping. Mind Mapping menggunakan prinsip menejemen otak untuk membuka seluruh potensi dan kapasitas otak yang tersembunyi. ${ }^{2}$ Cara ini membantu anak belajar secara efektif, efesien, dan menyenangkan. Mind Mapping mengutamakan dasar bahwa setiap anak adalah unik, karena pancaran pikiran (Radiant Thinking) setiap individu berbeda-beda. Dalam pembuatan Mind Mapping ada beberapa unsur yang dilakukan. Unsur tersebut antara lain dengan menuliskan pokok gagasan di tengah kertas, membuat cabang-cabang sub topik dengan warna-warna, membuat kata kunci dan menghubungkannya pada pokok gagasan, serta menyertakan gambar atau lambang dalam media Mind Mapping tersebut. Dari latar belakang tersebut di atas, maka peneliti bermaksud memecahkan permasalahan penggunaan media dalam pembelajaran dengan melakukan penelitian tindakan kelas (PTK) yang berjudul "Penerapan Mind Mapping sebagai Media dalam Meningkatkan Kemampuan Belajar IPS pada Siswa Kelas VII Mts Manbaul Bayan Sakra'.

\section{LANDASAN TEORI}

\section{A. Mind mapping}

Tony Buzan penemu metode ini mengemukakan bahwa Mind Map adalah sebuah "peta pikiran" yang menggunakan unsur-unsur utama dari memori, asosiasi, lokasi, keistimewaan, dan yang mengarahkan semua keterampilan otak kiri dan otak kanan. Mind Map juga membuat dan mendorong percepatan aliran berbagai pikiran kreatif dan inovatif berdasarkan sifat multi-ordinasi yang dimiliki oleh kenyataan sehingga membiarkan otak anak dibiarkan untuk menyatakan ekspresi dan ekspansi individualnya sendiri yang tak terbatas dengan cara sederhana namun penuh rahasia untuknya.

Mind Map berperan pada otak anak untuk melihat gambarangambaran yang telah mereka kenal (sebuah gambar bernilai ribuan kata) serta asosiasi dan berbagai hubungan yang mereka buat tanpa dibatasi oleh aturan tata bahasa dan sematik. Mind Map seketika memberikan gambaran menyeluruh kepada anak, sekaligus memberikan kesempatan baginya untuk menghimpun hal-hal yang terkait lebih erat satu sama lain. Mind Map bagi anak-anak merupakan alat menakjubkan yang bisa memberi mereka kesempatan untuk membuka diri dan menjelajahi ruang-ruang memori, pemahaman, pemikiran kreatif, analisis, persiapan untuk tugas sekolah, tinjauan dan ekspresi diri. ${ }^{3}$

B. Belajar

\section{Makna Belajar}

2 Tony, Buzan. Buku Pintar Mind Map: The Ultimate Book of Mind Maps. Jakarta: Gramedia Pustaka Utama: 2007

3 Tony, Buzan.. Buku Pintar Mind Map: The Ultimate Book of Mind Maps. Jakarta: Gramedia Pustaka Utama(2007).hal,76. 
belajar adalah suatu proses usaha yang dilakukan seseorang untuk memperoleh suatu perubahan tingkah laku yang baru secara keseluruhan, sebagai hasil pengalaman individu itu sendiri dalam interaksi dengan lingkungannya. Belajar juga merupakan proses mengasimilasikan dan menghubungkan pengalaman atau bahan yang dipelajari dengan pengertian yang sudah dipunyai seseorang sehingga pengertiannya dikembangkan. Proses tersebut antara lain bercirikan sebagai berikut:

1) Belajar berarti membentuk makna. Makna diciptakan oleh siswa dari apa yang mereka lihat, dengar, rasakan dan alami.

2) Proses belajar seharusnya terjadi pada waktu skema seseorang dalam keraguan yang merangsang pemikiran lebih lanjut. Situasi ketidakseimbangan (disequilibrium) adalah situasi yang baik untuk memacu belajar.

3) Hasil belajar dipengaruhi oleh pengalaman pelajar dengan dunia fisik dan lingkungan.

4) Hasil belajar seseorang tergantung pada apa yang telah diketahui si pelajar: konsepkonsep, tujuan, dan motivasi yang mempengaruhi interaksi dengan bahan yang dipelajari. 4

2. Kemampuan Belajar

prestasi adalah hasil yang dicapai seseorang ketika mengerjakan tugas atau kegiatan tertentu. Prestasi akademik merupakan hasil yang diperoleh dari kegiatan pembelajaran di sekolah yang bersifat kognitif dan biasanya ditentukan melalui pengukuran dan penilaian. Prestasi belajar merupakan penguasaan terhadap mata pelajaran yang ditentukan lewat nilai atau angka yang diberikan guru. Menurut kesimpulan penulis, kemampuan belajar merupakan hasil yang telah dicapai oleh peserta didik di dalam kegiatan belajar mengajar yang ditunjukkan dengan nilai tes atau angka dari hasil evaluasi yang diberikan oleh guru. Jadi prestasi belajar berfokus pada nilai atau angka yang dicapai dalam proses pembelajaran di sekolah. Nilai tersebut dinilai dari segi kognitif karena guru sering memakainya untuk melihat penguasaan pengetahuan sebagai pencapaian hasil belajar siswa. ${ }^{5}$

3. Evaluasi Belajar

Evaluasi merupakan suatu bagian pokok dalam pembelajaran yang digunakan untuk menentukan tingkat keberhasilan pembelajaran. Bagi guru, evaluasi merupakan alat untuk mengetahui apakah yang telah diajarkan sudah dipahami oleh siswa. Sedangkan bagi siswa, evaluasi belajar merupakan umpan balik tentang kelemahan dan kelebihan yang dimiliki siswa sehingga dapat mendorong siswa untuk meningkatkan motivasi belajar serta dapat belajar lebih baik lagi. Dalam penelitian ini, evaluasi belajar dilaksanakan sesaat sebelum pembelajaran (pretest), dan setelah pembelajaran dilaksanakan (posttest). Hal ini

\footnotetext{
${ }^{4}$ Slameto.. Belajar dan Faktor-faktor Yang Mempengaruhinya. Jakarta: Rineka Cipta 2007.hal,13.

${ }^{5}$ Tulus, Tu'u. Peran Disiplin pada Perilaku dan Prestasi Siswa. Jakarta: Rineka Cipta 2004.hal,75.
} 
bertujuan agar terlihat perbandingan kemampuan belajar siswa antara sebelum pembelajaran dilaksanakan dengan sesudah pembelajaran dilaksanakan dengan menggunakan media Mind Mapping.

4. Pengaruh Mind Mapping terhadap Hasil Belajar Siswa

Hasil belajar siswa meliputi aspek kognitif (pengetahuan), afektif (sikap), dan psikomotorik (tingkah laku). Hasil belajar tersebut dapat terlaksana apabila kinerja otak kanan dan otak kiri berkembang bersamaan. Hal tersebut berkaitan dengan otak kiri yang berhubungan dengan hal yang bersifat logis (seperti belajar), dan otak kanan yang berhubungan dengan kreativitas. Pemilihan media Mind Mapping sebagai media dalam belajar memungkinkan siswa untuk mengembangkan otak kanan dan otak kiri secara seimbang. Media Mind Mapping merupakan bentuk media yang memadukan fungsi kerja otak secara bersamaan dan saling berkaitan antara otak kiri dan otak kanan. Otak dapat menerima materi belajar yang berhubungan dengan otak kiri, namun menggunakan hal berupa gambar, simbol, dan warna yang juga memacu kerja dari otak kanan. Dengan demikian, maka media Mind Mapping diharapkan dapat meningkatkan hasil belajar siswa dengan mengembangkan kedua belah otak secara bersamaan.

5. Pembelajaran IPS

IPS yang kita kenal di Indonesia bukan ilmu sosial. Oleh karena itu, proses pembelajaran IPS pada berbagai tingkat pendidikan dasar sampai perguruan tinggi tidak menekankan aspek teoritis keilrnuannya, melainkan lebih menekankan kepada segi ptraktis mempelajari, menelaah serta mengkaji gejala dan masalah sosial, dengan mempertimbangkan bobot dan tingkat kemampuan peserta didik pada tiap jenjang yang berbeda.

Terdapat sejumlah perbedaan antara IPS dengan Ilmu-ilmu sosial (Social Sciences) antara lain:

a. IPS bukanlah suatu disiplin ilmu seperti halnya ilmu sosial, tetapi IPS lebih tepat dilihat sebagai bidang kajian, yaitu suatu kajian terhadap masalah-masalah kemas yarakatan

b. Pendekatan yang dilakukan dalam IPS menggunakan pendekatan multidisiplin atau interdisipili., tidak seperti halnya ilmu sosial yang menggunakan pendekatan disiplin ilmu atau monodisiplin.

c. IPS sengaja dirancang untuk kepentingan pendidikan oleh karena itu, keberadaan IPS lebih memfokuskan pada dunia persekolahan, tidak seperti ilmu sosial keberadaannya bisa di dunia persekolahan, perguruan tinggi atau dipelajari di masyarakat umum sekalipun.

d. IPS di samping menggunakan ilmu-ilmu sosial sebagai bahan pengembangan materi pembelajaran dilengkapi dengan mempertimbangkan aspek psikologis pedagogis. ${ }^{6}$

\footnotetext{
${ }^{6}$ Abdul Azis,Wahab. Konsep Dasar LPS. Jakarta: Universitas Terbuka 2008.hal,16.
} 


\section{Keaktifan Siswa}

Keaktifan siswa merupakan salah satu faktor utama dalam keberhasilan pembelajaran. Siswa yang aktif membuat pembelajaran menjadi lebih hidup dan tidak membosankan. Hal ini mendorong siswa agar lebih giat dalam belajar. Keaktifan siswa dapat diukur dengan beberapa indikator seperti bagaimana siswa mempersiapkan diri sebelum pembelajaran, suasana ruang kelas saat pembelajaran berlangsung, bagaimana siswa mengajukan pertanyaan atau pendapat, bagaimana siswa rajin dalam mencatat pelajaran, serta bagaimana cara siswa dalam mengerjakan soal-soal evaluasi.

7. Media Pembelajaran.

Media pembelajaran merupakan alat yang dapat digunakan guru sebagai penunjang proses pembelajaran agar lebih menarik perhatian siswa sekaligus meningkatkan pemahaman materi sehingga tujuan pembelajaran dapat tercapai sebagaimana mestinya. Berdasarkan klasifikasi media yang terdiri dari media auditif, media visual dan media audio visual. Maka peneliti akan menggunakan jenis media visual.

\section{METODOLOGI PENELITIAN}

1. Rancangan penelitian

Penelitian Tindakan Kelas atau PTK (Classroom Action Research) memiliki peranan yang sangat penting dan strategis untuk meningkatkan mutu pembelajaran apabila diimplementasikan dengan baik dan benar. Penelitian tindakan kelas dapat didefinisikan sebagai suatu penelitian tindakan yang dilakukan oleh guru atau berkolaborasi dengan orang lain dengan jalan merancang, melaksanakan, dan merefleksikan tindakan secara kolaboratif dan partisipatif yang bertujuan untuk meningkatkan kualitas proses pembelajaran di kelas melalui suatu tindakan tertentu dalam suatu siklus. Dalam PTK, penelitian dilakukan terhadap praktik pembelajaran di kelas, baik dari interaksi siswa ataupun hasil pembelajaran. Guru dapat mengadaptasi teori yang ada untuk kepentingan proses dan hasil pembelajaran yang lebih efektif, optimal, dan fungsional. $^{7}$

Penelitian tindakan kelas berfokus pada kelas atau proses belajar mengajar yang terjadi di dalam kelas. Obyek yang menjadi fokus penelitian tindakan kelas adalah siswa, guru, media atau alat peraga, hasil pembelajaran, sistem evaluasi pembelajaran, serta lingkungan baik di dalam kelas maupun di luar kelas. Sedangkan komponen yang dapat dijadikan kajian PTK adalah siswa, guru, materi pelajaran, media atau alat peraga, hasil pembelajaran, lingkungan pembelajaran, serta pengelolaan proses belajar mengajar. Dalam penelitian ini yang menjadi

\footnotetext{
${ }^{7}$ Suharsimi, Arikunto. Penelitian Tindakan Kelas. Jakarta: Bumi Aksara, 2008
} 
fokus penelitian adalah siswa, dengan menggunakan kajian terhadap media atau alat peraga serta hasil pembelajaran.

2. Subyek Penelitian

Subyek dalam penelitian tindakan kelas ini adalah siswa kelas VII Mts Manbaul Bayan Sakra pada Tahun Pelajaran 2021/2022 yang terdiri dari 15 orang siswa alat peraga serta hasil pembelajaran.

3. Tempat dan Waktu Penelitian

Penelitian ini dilaksanakan di Mts Manbaul Bayan Sakra yang terletak di jalan Desa kute timuk, Kecamatan sakra, Kabupaten Lombok Timur. Tempat penelitian ini dipilih karena sesuai dengan latar belakang penelitian yaitu mengembangkan media pembelajaran yang dapat digunakan pada sekolah yang masih terkendala oleh sarana dan prasarana pembelajaran dalam menggunakan media berbasis komputer. Penelitian dilaksanakan pada hari Rabu 13 oktober 2021 sampai dengan hari Rabu 27 oktober 2021. Penelitian dilaksanakan pada saat kegiatan belajar mengajar (KBM) mata pelajaran IPS di kelas VII berlangsung.

4. Teknik Pengumpulan Data

Teknik pengumpulan data yang digunakan adalah sebagai berikut:

a. Tes

Tes adalah serentetan pertanyaan atau latihan serta alat lain yang digunakan untuk mengukur keterampilan, pengetahuan intelegensi, kemampuan atau bakat yang dimiliki oleh individu atau kelompok. Tes ini digunakan untuk mendapatkan data hasil belajar kognitif siswa sebelum pembelajaran (pretest), serta setelah pembelajaran (posttest). Tes yang digunakan dalam penelitian ini berbentuk pilihan ganda. $^{8}$

b. Observasi

Observasi adalah kegiatan memperhatikan obyek penelitian dengan menggunakan seluruh indera dan berupa pengamatan langsung. Metode ini digunakan untuk mengukur tingkat kerja dan sikap siswa selama pembelajaran berlangsung, Dalam penelitian ini, peneliti menyiapkan lembar observasi keaktifan siswa dalam pembelajaran.

c. Dokumentasi

Dokumentasi adalah cara pengambilan data yang bersumber pada dokumen atau data tertulis yang meliputi daftar nama siswa, daftar nilai siswa, rencana pelaksanaan pembelajaran, serta catatan lain yang relevan dengan kebutuhan penelitian.

\section{Teknik Analisis Data}

\footnotetext{
${ }^{8}$ Suharsimi, Arikunto. Prosedur Penelitian Suatu Pendekatan Praktek. Jakarta: Rineka Cipta 2002.hal,127.
} 
Analisis data adalah suatu cara menganalisis data yang diperoleh selama peneliti mengadakan penelititan. Dalam penelitian ini, data yang perlu dianalisis adalah data berupa hasil tes evaluasi belajar siswa baik ketuntasan belajar individu ataupun ketuntasan belajar klasikal serta tingkat keaktifan siswa yang diperoleh dari setiap siklus.

6. Indikator Keberhasilan

Pembelajaran dengan penggunaan media Mind Mapping di kelas VII Mts Manbaul Bayan Sakra ini dikatakan berhasil apabila ketuntasan belajar klasikal sekurangkurangnya mencapai $71 \%$, atau dengan kata lain $71 \%$ siswa yang mengikuti posttest tuntas belajar dengan memperoleh nilai $\geq 62$. Adapun alat ukurnya adalah dengan menganalisis persentase ketuntasan belajar klasikal siswa berdasarkan nilai posttest soal penilaian yang dikerjakan oleh siswa pada tiap siklus.

\section{PEMBAHASAN}

1. Media mind mapping

Penerapan media mind mapping dalam penelitian ini terbukti dapat meningkatkan kemampuan belajar siswa. Beberapa kelebihan dalam pemanfaatan mind mapping sebagai media pembelajaran adalah:

a. Media mind mapping dapat dibuat dengan mudah dan relatif murah

b. Dapat diaplikasikan pada pembelajaran yang terbatasi oleh ketersediaaan sarana dan prasarana penggunaan media berbasis komputer.

c. Dapat digunakan oleh guru yang tidak dapat mengoprasikan komputer

d. Memudahkan guru untuk menjelaskan materi kepada siswa

e. Memudahkan siswa dalam memahami materi secara menyeluruh dan terkonsep

f. Materi yang telah dipelajari mudah dikilas balik oleh guru

2. Siswa

Siswa menjadi obyek dalam penelitian ini, siswa berperan penting dalam pelaksanaan penelitian. Dalam penelitian ini, aktivitas siswa mengalami peningkatan dari siklus 1, siklus II, perhatian yang diberikan siswa dalam pembelajaran membuat siswa menjadi aktif dalam pembelajaran. Perubahan tingkah laku siswa tidak lepas dari peran guru yang selalu mengingatkan siswa agar siswa fokus dalam pembelajaran dan tidak bermain sendiri saat pembelajaran berlangsung. Melalui data observasi pada siklus I terlihat bahwa siswa masih bermain sendiri saat pembelajaran berlangsung. Namun guru sering mengingatkan siswa agar bisa fokus dalam belajar, sehingga pada siklus II mengalami peningkatan sikap siswa dalam belajar.

3. Hasil belajar

Hasil belajar menjadi patokan dalam pelaksanaan penelitian. Peningkatan hasil belajar siswa tidak lepas dari materi yang digunakan dalam pembelajaran. Siswa telah belajar 
beberapa hal terkait materi interaksi sosial . secara keseluruhan, peningkatan hasil penelitian tersebut dapat dibandingkan dalam tabel rekapitulasi, serta aktivitas siswa pada pelaksanaan siklus 1 dan II.

\section{Rekapitulasi hasil penelitian}

\begin{tabular}{|l|l|l|l|l|}
\hline \multirow{2}{*}{ Pelaksanaan hasil } & \multicolumn{2}{l|}{ Siklus I } & \multicolumn{2}{l|}{ Siklus II } \\
\cline { 2 - 5 } & pretest & posttest & Pretest & posttest \\
\hline Rata -rata & 49,64 & 53,57 & 51,92 & 72,31 \\
\hline Nilai terendah & 30 & 20 & 10 & 30 \\
\hline Nilai tertinggi & 90 & 90 & 100 & 100 \\
\hline Jumlah siswa tuntas & $3 / 28$ & $7 / 28$ & $7 / 26$ & $20 / 26$ \\
\hline Presentase ketuntasan klasikal & $10,7 \%$ & $25 \%$ & $26,92 \%$ & $76,92 \%$ \\
\hline Aktivitas siswa & $60 \%$ & $73,33 \%$ & \\
\hline
\end{tabular}

\section{KESIMPULAN}

Penerapan Mind Mapping sebagai media pembelajaran terbukti efektif dalam meningkatkan kemampuan belajar IPS pada siswa Kelas VII Mts Manbaul Bayan Sakra tahun pelajaran 2021/2022. Hal ini didukung oleh hasil penelitian berupa peningkatan prestasi belajar siswa yang signifikan antara sebelum siklus dilaksanakan dengan setelah siklus terlaksana. Berdasarkan hasil penelitian ini, maka peneliti menyimpulkan bahwa penerapan Mind Mapping sebagai media pembelajaran mampu meningkatkan kemampuan belajar secara signifikan, tidak hanya pada pembelajaran penelitian ini namun juga terhadap pembelajaran lain yang menggunakan Mind Mapping sebagai media pembelajaran. 


\section{DAFTAR PUSTAKA}

Arikunto, Suharsimi. 2002. Prosedur Penelitian Suatu Pendekatan Praktek. Jakarta: Rineka Cipta.

Arikunto, Suharsimi. 2008. Penelitian Tindakan Kelas. Jakarta: Bumi Aksara

Buzan, Tony. 2007. Buku Pintar Mind Map: The Ultimate Book of Mind Maps. Jakarta: Gramedia Pustaka Utama

Rosidah, Ummu. 2009. Penerapan Teknik Mind Map untuk Meningkatkan Hasil Belajar IPS Siswa Kelas V SDN Tamansatriyan 2 Tirtoyudo Kabupaten Malang. Universitas Negeri Malang.

Slameto. 2003. Belajar dan Faktor-faktor Yang Mempengaruhinya. Jakarta: Rineka Cipta Tu’u,Tulus. 2004. Peran Disiplin pada Perilaku dan Prestasi Siswa. Jakarta: Rineka Cipta. Wahab, Abdul Azis. 2008. Konsep Dasar LPS. Jakarta: Universitas Terbuka 